E3 Journal of Environmental Research and Management Vol. 8(2). pp. 011-017, June, 2017

Available online http://www.e3journals.org

ISSN 2141-7466 @ E3 Journals 2017

DOI : http://dx.doi.org/10.18685/EJERM(8)2_EJERM-17-011

\title{
Accumulation of Zinc by Pteridium aquilinum (bracken fern) with different plant stimulants and bioassay with Clarias gariepinus
}

\author{
Olaifa, Flora E. Ajagbe, Abdulazeez 0. \\ Department of Aquaculture and Fisheries Management, University of Ibadan, Ibadan, Nigeria
}

Accepted 16 May, 2017

\begin{abstract}
An experiment was carried out to determine the ability of Pteridium aquilinum to accumulate zinc from solutions containing $10 \mathrm{mg} / \mathrm{l}$ zinc and $10 \mathrm{mg} / \mathrm{l}$ of different inorganic and organic manures and to assess the effect of zinc on Clarias gariepinus. A 96-hour bioassay was carried out using Clarias gariepinus juveniles to determine the effect of its exposure on haematology and histology. The water and P.aquilinum were also analysed for zinc and other parameters. Variations were observed in haematological parameters such as Red blood cell, Packed cell volume, White blood cell, Haemoglobin and enzymes (Serum Glutamic - Oxaloacetic Transaminase, SGOT and Serum Glutamic - Pyruvic Transaminase, SGPT),while platelet and total protein showed no significant difference. Damage observed in organs included necrosis, cell individualization and disorganization and congestion.
\end{abstract}

Keywords: zinc, Clarias gariepinus, bracken fern, haematology, histology

\section{INTRODUCTION}

Zinc is an abundant transition metal, an essential trace element for plants, animals, microorganisms and several enzymes (Broadley et al., 2007)). It is an essential mineral of biological and public health importance considered a life -saving commodity by the United Nations useful in a wide range of consumer goods, agricultural and industrial products (International Zinc Association, 2017). Zinc is a structural ion in transcription factors which is stored and transferred in metallothioneins - small cysteine-rich and heavy-metal-binding proteins which participate in an array of protective stress responses (Ruttkay- Nedecky et al, 2013).

Zinc interacts with several ligands (Hambidge and Krebs, 2007), functions in Ribonucleic Acid (RNA) and Deoxyribonucleic Acid (DNA) metabolism, gene expression (Frassinetti et al., 2006), signal transduction, apoptosis regulation, synaptic plasticity and learning (Nakashima and Dyek, 2009). It is the only metal

\footnotetext{
${ }^{*}$ Corresponding authors: E-mail: floraolaifa@yahoo.com
}

represented in all six classes of enzymes-oxidoreductases, transferases, hydrolases, lyases, isomerases, and ligases (Bouain, et al, 2014). Its homeostasis is important for the functioning of the brain and central nervous system, electron transfer in catalytic reactions, growth and reproduction but can accumulate in tissues and become toxic when in excess (Javed, 2012). Zinc deficiency causes loss of appetite, inability to gain weight, skeletal abnormalities, parakeratotic oesophageal, and skin lesions, delayed wound healing (Trevisan et al., 2014).

Fish can accumulate zinc in zinc -contaminated waterways. Within the bodies of fish, zinc can magnify up the food chain while plants often have a zinc uptake their systems cannot handle due to accumulation of zinc in the soil. Only limited number of plants can survive zinc -rich soils (Lenntech, 2017). Bracken fern has been employed for the phytoremediation of water polluted by copper (Olaifa and Omekam, 2014). This experiment was carried out to determine the ability of Pteridium aquilinum (bracken fern) to accumulate zinc from solutions containing $10 \mathrm{mg} / \mathrm{l}$ zinc and $10 \mathrm{mg} / \mathrm{l}$ of different inorganic 
and organic manures and to assess the effect of zinc on Clarias gariepinus in the presence of a fertilizer and organic manures.

\section{MATERIALS AND METHODS}

The ability of the fern, $P$. aquilinum, to accumulate zinc from water into its tissues was tested in water containing Nitrogen-phosphorus -potassium fertilizer (15:15:15), pig, poultry, cattle and pig/cattle manure manures $(10 \mathrm{mg} / \mathrm{l}$. $0.2 \mathrm{~g}$ in $20 \mathrm{~L}$ of water ) and zinc ( as zinc chloride, 10mg/l), (Ndimele, 2009; Olaifa and Omekam, 2014). Zinc $(10 \mathrm{mg} / \mathrm{L})$ as zinc chloride was measured and introduced into tanks containing $20 \mathrm{~L}$ of water, $10 \mathrm{mg} / \mathrm{l}$ fertilizer or manures and left to stand for 2 weeks with Pteriduim aquilinum. Each manure or fertilizer represented a treatment with the control having no zinc or manure.

A 96-hour bioassay was carried out with juveniles of Clarias gariepinus juveniles at the end of the two weeks. Each treatment contained ten $C$. gariepinus juveniles (mean weight $35 \mathrm{~g}$; standard and total lengths 14.5 and $16.5 \mathrm{~cm}$ respectively) and two replicates. The bowls showing the $P$. aquilinum in water during the period of acclimatization are shown on plate 1 .

Physico-chemical parameters of the water (temperature, $\mathrm{pH}$, nitrate, phosphate, dissolved oxygen, alkalinity, potassium and zinc) were measured at the beginning and end of the experiment. A mercury-in-glass thermometer was dipped into each bowl for two minutes with the bulb fully immersed before recording the temperature. Nitrate and phosphate were measured at 470 and $882 \mathrm{~nm}$ respectively (Murphy and Riley, 1962). Alkalinity was determined by titration with hydrochloric acid against $50 \mathrm{ml}$ of water sample treated with 3 drops methyl orange as indicator until a peach colour was obtained. A digital pH meter (HANNA Instruments) was used to obtain the $\mathrm{pH}$ of each water sample. Dissolved oxygen was determined using Winkler's method (Montgomery et al, 1990) and calculated as:

D.O in $\mathrm{mg} / \mathrm{L}=$ (ml of titrant) $(\mathrm{N})(8)(1000)$

Sample volume in $\mathrm{ml}$

Where $N=1$, the normality of solution for titrating the sample

\section{Collection of Blood Samples}

Blood was drawn from the posterior caudal vein of fish (Schmitt et al., 1999) and analyzed for packed cell volume, red blood cells, white blood cells, mean corpuscular volume, mean corpuscular haemoglobin concentration, mean corpuscular volume, platelets, haemoglobin, total protein, neutrophils, albumin, serum glutamic pyruvic transaminase (SGPT) and serum glutamic oxaloacetic transaminase (SGOT) (Hesser,
1960; Dacie and Lewis, 1975; Jain, 1986). Fish and $P$. aquilinum samples for metal analyses were digested using total element analysis by perchloric and hydrochloric acid digestion (Pratt, 1965). $0.5 \mathrm{~g}$ of the milled samples were weighed out in a $25 \mathrm{ml}$ volumetric flask and $5 \mathrm{mls}$ of the acid mixture of perchloric and hydrochloric acid solution added. The volumetric flask and its content were heated on a hot plate for 45 minutes-1hour at a temperature between $150^{\circ} \mathrm{C}$ and $200^{\circ} \mathrm{C}$ until a clear coloured solution was obtained and allowed to cool. Deionized water was added to make up to the $25 \mathrm{ml}$ mark. Water samples were filtered before analysis. Atomic Absorption Spectrophotometer (AAS) was used to determine the concentration of zinc present in water and tissues of $P$. aquilinum and Clarias gariepinus. The concentration of zinc was calculated as:

Actual concentration $=$ Dilution factor $\times$ Volume of digest sample $x$ AAS reading

Weight of sample

For histopathological examination, gills, livers and kidneys were removed from sacrificed fish, preserved in $10 \%$ buffered formalin for 24 hours and processed (MAFF, 1984).

\section{RESULT}

The results obtained during this study are presented in tables $1-5$ and figures 1-9.

There was no recorded mortality up to $50 \%$, therefore the LC50 could not be calculated in all treatments.

Values in the same rows with different superscripts are significantly different. Note: $P C V=$ packed cell volume, $\mathrm{WBC}=$ white blood cell, $\mathrm{RBC}=$ red blood cell, $\mathrm{TP}=$ total protein, $\quad L Y M=$ lymphocyte, $\quad P L T=$ platelet, $\mathrm{HB}=$ haemoglobin, NEUT=neutrophil, $\quad \mathrm{ALB}=$ albumin, SGOT $($ AST $)$ = serum glutamic-oxaloacetic transaminase (aspartate amino-transferase), SGPT (ALT) = Serum Glutamic-Pyruvic Transaminase (Alanine AminoTransferase)

\section{DISCUSSION}

Physicochemical properties of the tap water, water in experimental containers were determined at the onset and end of the experiment (Tables 1 and 2) and showed changes in water quality parameters before and after the experiment. Dissolved oxygen and temperature decreased while alkalinity and phosphate contents of the water increased at the end of the experiment. Bubbles were observed on water surface of treatments which may have been due to low levels of dissolved oxygen. 


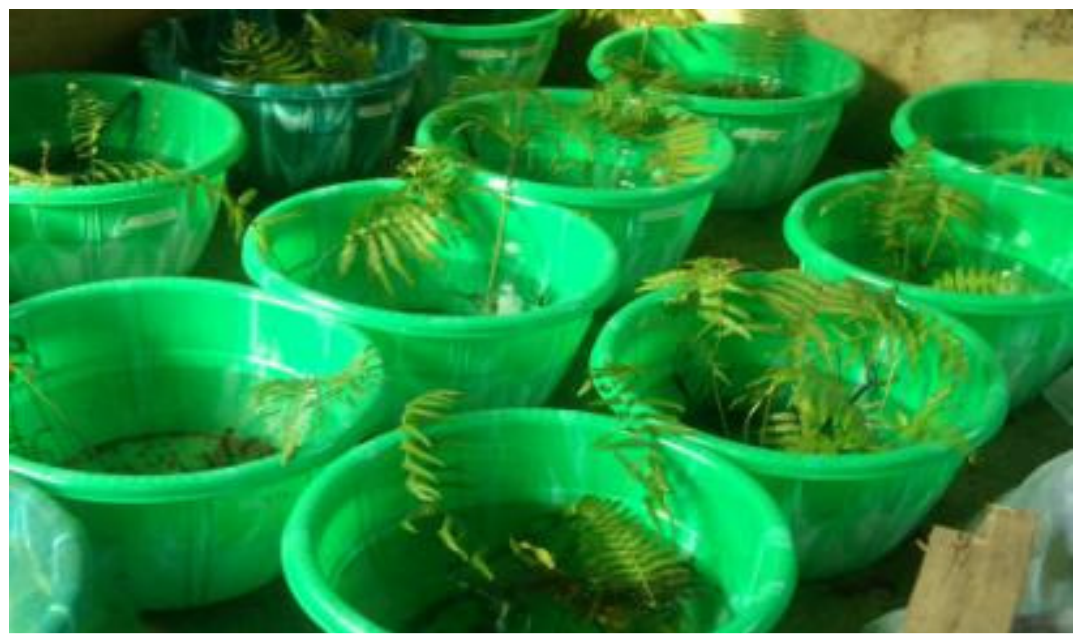

Plate 1: Pteridium aquilinum during acclimatization

Table 1: Water quality of the tap water used for the study

\begin{tabular}{ll}
\hline Parameters & Values \\
\hline PH & 7.4 \\
Temperature (o-C) & 26.5 \\
Alkalinity (mg/L) & 26 \\
Dissolved oxygen (mg/L) & 7.8 \\
Nitrate (mg/L) & 0.09 \\
Phosphate (mg/L) & 0.08 \\
Potassium (mg/L) & 5.4 \\
Zinc (mg/L) & 0.01 \\
\hline
\end{tabular}

Table 2: Water Quality Parameters at the Onset and End of Experiment Containing 10mg/L of Zinc and Different manures.

\begin{tabular}{|c|c|c|c|c|c|c|}
\hline Parameters/Fertilizers & Control & NPK & Pig & Poultry & Cow & Pig \& Cow \\
\hline \multicolumn{7}{|l|}{$\mathrm{pH}$} \\
\hline Onset & 7.4 & 6.7 & 7.2 & 6.9 & 7.3 & 6.8 \\
\hline After & 7.2 & 7.1 & 6.9 & 7.2 & 6.8 & 6.9 \\
\hline \multicolumn{7}{|l|}{ Temperature $\left({ }^{\circ} \mathrm{C}\right)$} \\
\hline Onset & 24.5 & 25.5 & 26.5 & 26.0 & 26.5 & 26.0 \\
\hline After & 22 & 23.5 & 22.5 & 23.0 & 23.0 & 23.5 \\
\hline \multicolumn{7}{|l|}{ Alkalinity $\left(\mathrm{mgL}^{-1}\right)$} \\
\hline Onset & 27.4 & 26.0 & 29.0 & 25.2 & 29.4 & 30.0 \\
\hline \multirow{2}{*}{\multicolumn{7}{|c|}{ Dissolved oxygen (mg/L) }} \\
\hline & & & & & & \\
\hline Onset & 7.8 & 6.7 & 6.9 & 5.9 & 6.1 & 6.2 \\
\hline \multirow{2}{*}{\multicolumn{7}{|c|}{ Phosphate (mg/L) }} \\
\hline & & & & & & \\
\hline Onset & 0.08 & 10.88 & 0.16 & 0.18 & 0.31 & 0.37 \\
\hline After & 9.22 & 86.0 & 10.82 & 27.2 & 10.78 & 14.59 \\
\hline \multicolumn{7}{|l|}{ Potassium (mg/L) } \\
\hline Onset & 0.54 & 2.03 & 0.10 & 0.58 & 1.12 & 2.08 \\
\hline After & 1.05 & 2.87 & 0.11 & 2.42 & 1.16 & 2.49 \\
\hline \multicolumn{7}{|l|}{ Nitrate (mg/L) } \\
\hline Onset & 0.46 & 2.49 & 0.09 & 1.39 & 0.14 & 2.14 \\
\hline \multirow{2}{*}{\multicolumn{7}{|c|}{ Zinc (mg/L) }} \\
\hline & & & & & & \\
\hline Onset & 0.01 & 0.02 & 0.01 & 0.02 & 0.03 & 0.02 \\
\hline After & 0.02 & 0.03 & 0.06 & 0.04 & 0.00 & 0.03 \\
\hline
\end{tabular}


Table 3: Percentage mortality of C. gariepinus in 96 hours in water containing $10 \mathrm{mg} / \mathrm{l}$ zinc and $10 \mathrm{mg} / \mathrm{l}$ Manure or fertilizer

\begin{tabular}{lccc}
\hline Fertilizer & Number of test fish & \%Mortality (Replicate 1) & \%Mortality (Replicate 2) \\
\hline Control & 10 & - & - \\
NPK fertilizer & 10 & 20 & 10 \\
Pig manure & 10 & - & - \\
Poultry manure & 10 & 10 & 10 \\
Pig and cow manure & 10 & 20 & 30 \\
Cattle manure & 10 & 10 & 20 \\
\hline
\end{tabular}

Table 4: Concentrations of zinc in C. gariepinus and Pteridium aquilinum at the end of the experiment $(\mathrm{mg} / \mathrm{g})$

\begin{tabular}{cccccc}
\hline $\begin{array}{c}\text { Fertilizer/ } \\
\text { manure }\end{array}$ & $\begin{array}{c}\text { Initial } \\
\text { concentration in } \\
\text { water (mg/L) }\end{array}$ & $\begin{array}{c}\text { Zn concentration } \\
\text { in fish } \\
\text { (Replicate1) }\end{array}$ & $\begin{array}{c}\text { Zn concentration } \\
\text { in fish } \\
\text { (Replicate2) }\end{array}$ & $\begin{array}{c}\text { Zn concentration in } \\
\text { plant (Replicate1) }\end{array}$ & $\begin{array}{c}\text { Zn concentration in } \\
\text { plant (Replicate 2) }\end{array}$ \\
\hline $\begin{array}{c}\text { Control } \\
\text { NPK }\end{array}$ & 10 & 0.01 & 0.02 & 0.02 & 0.02 \\
fertilizer & 10 & 0.01 & 0.04 & 0.01 & 0.13 \\
Pig manure & 10 & 0.01 & 0.02 & 0.13 & 0.14 \\
$\begin{array}{c}\text { Poultry } \\
\text { manure }\end{array}$ & 10 & 0.01 & 0.05 & 0.06 & 0.07 \\
$\begin{array}{c}\text { Cattle } \\
\text { manure } \\
\text { Cattle and } \\
\text { pig }\end{array}$ & 10 & 0.00 & 0.00 & 0.01 & 0.01 \\
Manure & 10 & 0.01 & 0.04 & 0.19 & 0.01 \\
\hline
\end{tabular}

Physical parameters of water such as temperature, $\mathrm{pH}$, water hardness and organic matter content affect the toxicity of metals in solution. Decreasing hardness and increasing $\mathrm{pH}$ tend to increase the toxicity of zinc to fish (Ezeonyejiaku et al, 2010). The changes in water quality could have been due to the presence of zinc in water, the metabolic activities of the fish and the decomposition of organic matter present in the manures and fertilizer (Tawari-Fufeyin et al, 2008; Olaifa and Omekam, 2014).

Zinc is a trace element essential for the health of man and animals required for growth, development of bones, metabolism and healing of wounds. However, excess amounts of trace metals in water can produce negative effects on fish and water quality (Lenntech, 2017; Jabeen and Javed, 2011). During this study, $10 \mathrm{mg} / \mathrm{l}$ of zinc in 20 litres of water containing different manures and a fertilizer despite the presence of $P$. aquilinum caused weakness and slow movement in Clarias gariepinus juveniles. After 18 hours of exposure, fish were weak and the first mortality was reported at 31 hours in the treatment containing NPK (15:15:15) fertilizer but the highest mortality $(30 \%)$ was recorded in the treatment containing cow and pig manure mixture (Table 3). This may be attributed to the direct toxicity of the metal to the fish, reduction in dissolved oxygen with bubbles on water surface in all treatments except the control.

Zinc uptake by $C$.gariepinus and P.aquilinum were low ranging from 0.0-0.19 $\mathrm{mg} / \mathrm{l}$ (Table 4 ). Zinc bioavailability and toxicity to aquatic organisms are highest under conditions of low pH, low alkalinity, low dissolved oxygen and elevated temperature. Soluble chemical species of zinc are the most bioavailable and toxic. Water hardness is the principal modifier of acute zinc toxicity. The bioavailabilty of zinc is higher in media with a low $\mathrm{pH}$, as a result of increased zinc solubility and ionization (Agency for Toxic Substances and Disease Registry, 2005). Increased alkalinity or water hardness decreases zinc toxicity to freshwater organisms. High temperatures and low dissolved oxygen tend to increase zinc toxicity (Gul et al., 2009). Decreasing hardness and the increasing $\mathrm{pH}$ increases the lethality of dissolved zinc (Ezeonyejiaku et al., 2012).

All haematological (Table 5) indices except total protein and platelets showed significant differences $(p<0.05)$ among C. gariepinus exposed to $10 \mathrm{mg} / \mathrm{L}$ zinc in all treatments containing a fertilizer (NPK, 15:15:15), pig manure, poultry, cattle, cattle and pig manure. The PCV was highest in NPK -containing treatment but lower than the control. An excess of zinc can result in decreased availability of dietary copper and the development of copper deficiency and induces a reversible anaemia in experimental animal (Agency for Toxic Substances and Disease Registry, 2005). Serum Glutamic Oxaloacetic Transaminase (SGOT) and Serum Glutamic Pyruvic Transaminase (SGPT) differed significantly $(p<0.05)$ in all treatments from both the initial measurements and the control. Reports by other workers show that metallothionein synthesis is induced when fish and other 
Table 5: Haematology of C. gariepinus exposed to $10 \mathrm{mg} / \mathrm{L}$ zinc and manures after 96 - hour bioassay

\begin{tabular}{|c|c|c|c|c|c|c|c|}
\hline $\begin{array}{l}\text { Haematological } \\
\text { Parameters }\end{array}$ & Initial & Control & NPK fertilizer & $\begin{array}{l}\text { Poultry } \\
\text { manure }\end{array}$ & $\begin{array}{l}\text { Cattle } \\
\text { manure }\end{array}$ & $\begin{array}{c}\text { Pig } \\
\text { manure }\end{array}$ & $\begin{array}{l}\text { Pig and cattle } \\
\text { manure }\end{array}$ \\
\hline PCV & $19.50^{\text {ab }}$ & $24.00^{\mathrm{ab}}$ & $25.00^{\mathrm{a}}$ & $23.00^{\mathrm{ab}}$ & $13.00^{\mathrm{b}}$ & $15.00^{\mathrm{ab}}$ & $19.00^{\mathrm{ab}}$ \\
\hline WBC & $5.80^{\mathrm{C}}$ & $4.80^{\mathrm{C}}$ & $10.40^{\mathrm{b}}$ & $8.80^{\mathrm{b}}$ & $4.00^{c}$ & $5.60^{c}$ & $17.60^{\mathrm{a}}$ \\
\hline $\mathrm{HB}$ & $6.45^{\mathrm{b}}$ & $7.90^{\mathrm{a}}$ & $8.20^{\mathrm{a}}$ & $7.70^{\mathrm{a}}$ & $4.20^{\mathrm{C}}$ & $4.90^{c}$ & $6.20^{\mathrm{b}}$ \\
\hline PLT & 5.00 & 6.00 & 6.00 & 6.00 & 3.00 & 4.00 & 5.00 \\
\hline $\mathrm{RBC}$ & $2.70^{\mathrm{e}}$ & $5.28^{a}$ & $4.92^{\mathrm{ab}}$ & $4.42^{\mathrm{bc}}$ & $3.82^{\mathrm{cd}}$ & $3.40^{\text {de }}$ & $4.64^{\mathrm{ab}}$ \\
\hline TP & 2.05 & 2.40 & 2.60 & 2.20 & 1.20 & 1.80 & 2.00 \\
\hline LYM & $55.50^{c}$ & $60.00^{\mathrm{ab}}$ & $56.00^{\mathrm{b}}$ & $54.00^{c}$ & $64.00^{\mathrm{a}}$ & $62.00^{\mathrm{ab}}$ & $58.00^{\mathrm{b}}$ \\
\hline NEUT & $43.50^{\mathrm{a}}$ & $38.00^{\mathrm{D}}$ & $42.00^{\mathrm{ab}}$ & $45.00^{\mathrm{a}}$ & $35.00^{c}$ & $37.00^{\mathrm{b}}$ & $40.00^{\mathrm{ab}}$ \\
\hline ALB & $0.705^{\mathrm{bc}}$ & $1.00^{\mathrm{ab}}$ & $1.10^{\mathrm{a}}$ & $1.00^{\mathrm{ab}}$ & $0.60^{\mathrm{C}}$ & $0.70^{\mathrm{bc}}$ & $0.90^{\mathrm{ab}}$ \\
\hline SGOT & $32.50^{\mathrm{ab}}$ & $40.00^{a}$ & $42.00^{\mathrm{a}}$ & $37.00^{\mathrm{ab}}$ & $10.00^{c}$ & $22.00^{\mathrm{bc}}$ & $26.00^{\mathrm{abc}}$ \\
\hline SGPT & $41.50^{\mathrm{bcd}}$ & $52.00^{\mathrm{ab}}$ & $56.00^{a}$ & $48.00^{\mathrm{abc}}$ & $18.00^{\mathrm{e}}$ & $34.00^{d}$ & $36.00^{\mathrm{cd}}$ \\
\hline
\end{tabular}

Values in the same rows with different superscripts are significantly different. Note: $P C V=$ packed cell volume, WBC=white blood cell,

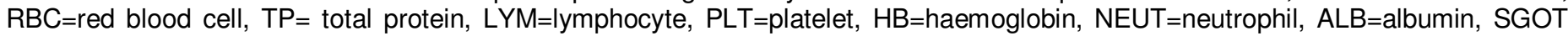
$($ AST $)=$ serum glutamic-oxaloacetic transaminase (aspartate amino-transferase), SGPT (ALT) = Serum Glutamic-Pyruvic Transaminase (Alanine Amino-Transferase) Histology

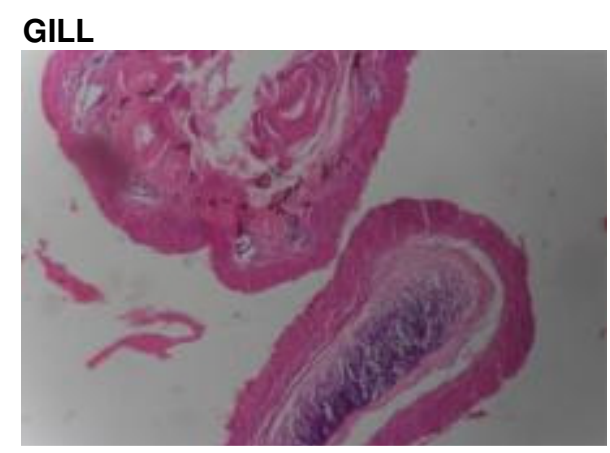

Plate 1: Photomicrograph of gill of Clarias gariepinus juvenile in control C.gariepinus showing well organized lamella cells (x250).

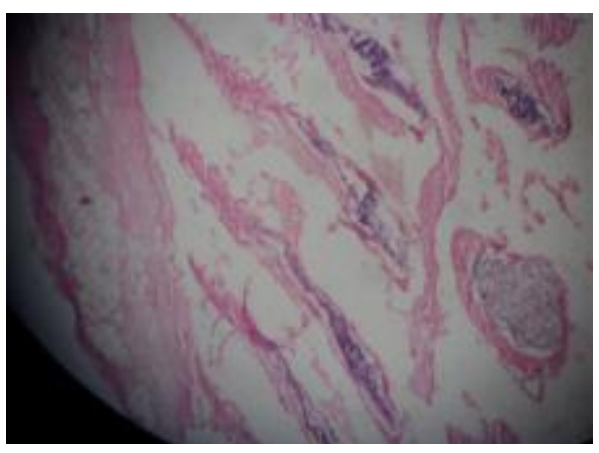

Plate 2: Photomicrograph of gill of Clarias gariepinus juvenile observed in pig, cattle, pig and cattle manure -containing treatments showing disorganized lamella cells (x250).

animals are exposed to metals such as zinc and protect the fish by sequestering the zinc more effectively in order

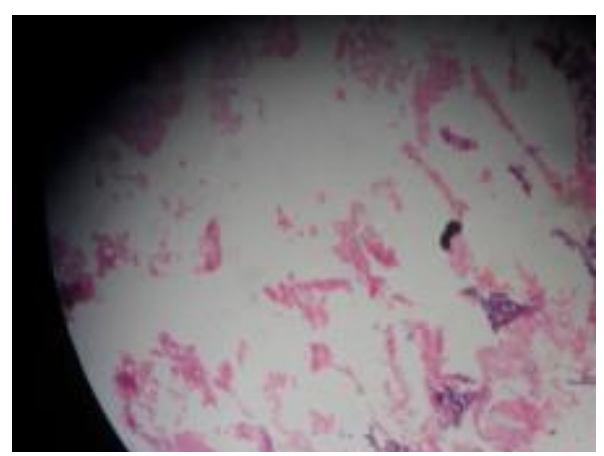

Plate 3: Photomicrograph of gill of Clarias gariepinus juvenile observed in poultry manure and NPK manure containing treatments with completely disorganized lamella cells gone (x250).

to detoxify the animal (Langston et al, 2002). In blood plasma, $\mathrm{Zn}$ is bound to and transported by albumin $(60 \%$, low-affinity) and transferrin (10\%) (Whitney and Rolfes, 2010). Since transferrin also transports iron, excessive iron can reduce zinc absorption, and vice-versa (Valko et al., 2005).

Damage observed in organs (gill, liver and kidney) were similar in all the treatments (Figures 1-9). The gill of the fish in the control had well organized lamellae while those in all treatments were disorganized and necrotic. Gills of fish are in intimate contact with the water and play important roles in ionic and osmotic regulation (Javed, 2012). The liver serves as stores and organ of detoxification (Javed, 2012) and was the most damaged organ with the complete individualization and 


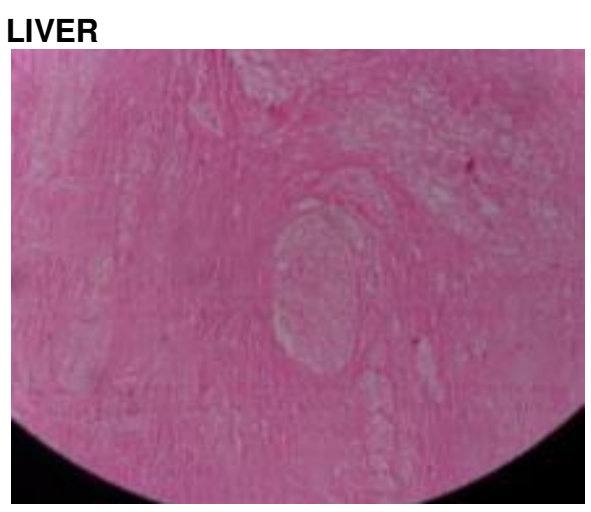

Plate 4: Photomicrograph showing congested liver cells of Clarias gariepinus juvenile observed in control (x250).

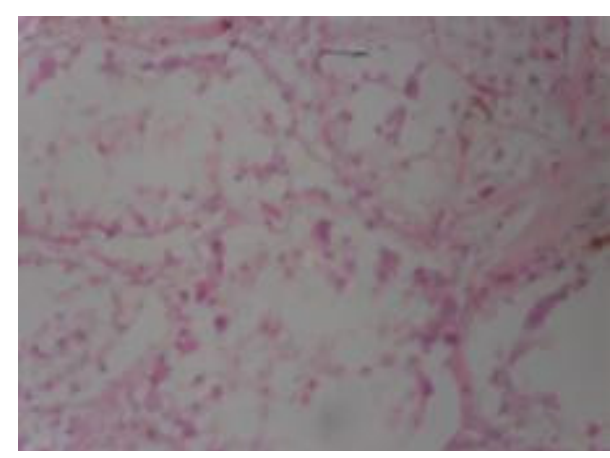

Plate 5: Photomicrograph showing total individualization and disorganization of liver cells in Clarias gariepinus juvenile observed in pig, cattle, pig and cattle manure- containing treatments (x250).

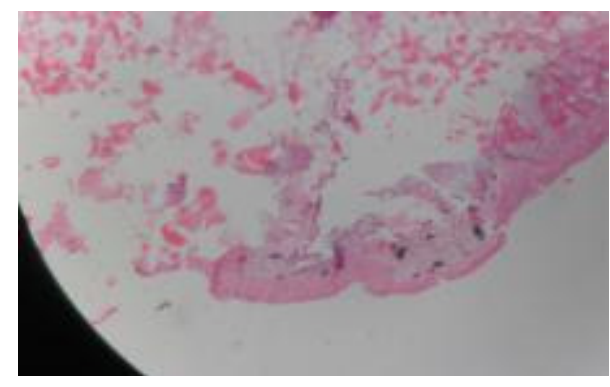

Plate 6: Photomicrograph showing total individualization and disorganization of hepatocytes in Clarias gariepinus juvenile observed in poultry manure and NPK fertilizer- containing treatments (x250).

disorganization of the hepatocytes. The kidney of fish also showed severe necrotic lesions in all treatments. The main target of water-borne $\mathrm{Zn}$ toxicity are the gills (Hogstrand, 2011).

Zinc accumulates in tissues and organs of freshwater fish (Murugan et al., 2008) and may upset osmoregulation and cause histopathological organ damage (Hallajian et

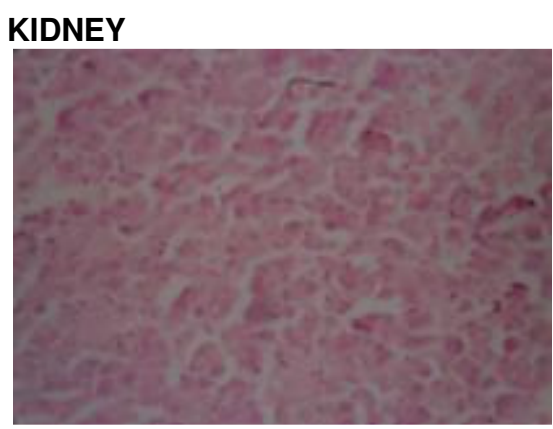

Figure 7: Photomicrograph showing kidney of Clarias gariepinus observed in control (x250).

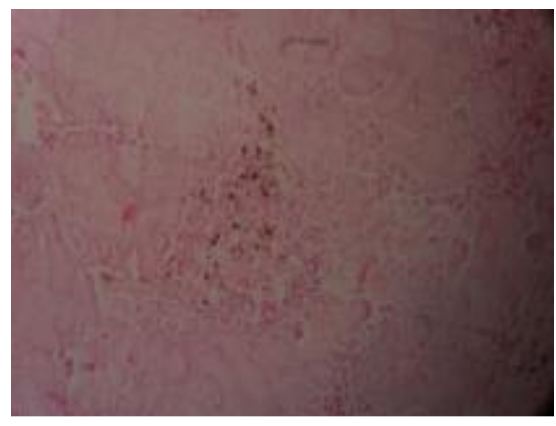

Figure 8: Photomicrograph showing congestion in kidney of Clarias gariepinus marked with necrosis observed in Pig, cattle, pig and cattle manure- containing treatments (x250)

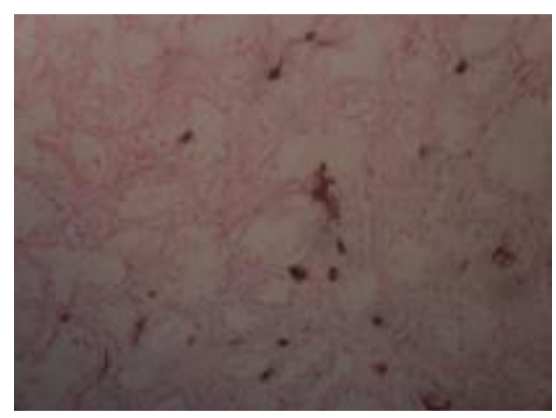

Figure 9: Photomicrograph showing congestion in kidney of Clarias gariepinus marked with necrosis observed in poultry manure and NPK fertilizer (x250)

et al., 2013). Zinc may negatively effect blood serum (Fırat and Kargın, 2010a, b), haematological and immune parameters of the fish (Ololade and Ogini, 2009) and thus diseases and death. Zinc toxicity to fish is highest at early developmental stages, in soft water, low alkalinity, low pH and dissolved oxygen and at elevated temperature. Both the redox cycling of heavy metals and their interaction 
with organic pollutants contribute to oxidative stress due to aquatic

pollution (Geeraerts and Belpaire, 2010). Disturbances inthe normal oxidation-reduction states of the fish can produce toxic effects that can damage all cell components such as protein, lipids and deoxyribonucleic acid (Geeraerts and Belpaire, 2010). The level of bioaccumulation of toxicants depends on the level of pollution and individual's ability to detoxify or excrete the pollutant (van Ginneken et al. 2009). P. aquilinum in both poultry manure and NPK fertilizer-containing treatments wilted completely during the experiment. High content of phosphate in NPK and poultry manure- containing treatments at the end of the experiment could have played a role in zinc toxicity to the $P$. aquilinum which was similar to other reports. This was similar to the observations that despite its essentiality, high concentrations of zinc in the growth medium can cause toxicity in plants (Bouain et al, 2014). At cellular level, elevated zinc concentration causes oxidative stress, a decrease in accumulation of ATP, disintegration of cell organelle and development of vacuoles (Xu et al, 2013). Zinc was not accumulated to a large extent by Clarias gariepinus and $P$. aquilinum as distinct from observations in studies on copper (Olaifa and Omekam, 2014).

For essential elements such as zinc, environmental effects must be considered within the context of an organisms' natural ability to regulate (Uptake and excretion) and maintain a certain level of homeostasis. Environments containing zinc at very low or very high concentrations may produce undesirable effects. The range between the minimal and maximum is called the optimal window of essentiality (International zinc association, 2017). Once mobilized in to the environment, zinc interacts with the different components of water, sediments, soils and ultimately partitions between different fractions in these environmental compartments. The interaction and the dynamic processes involved ultimately define zinc's environmental fate .i.e. the forms in which the metal will be present in the environment and in which it will ultimately end up

\section{CONCLUSION AND RECOMMENDATION}

Phytoremediation is a very good cleanup method for polluted sites, but has a major disadvantage of long duration before cleaning up the environment. Zinc was not efficiently remediated by $P$. aquilinum during this study. This could be due to several reasons such as inadequate length of time allowed for the uptake of zinc by $P$. aquilinum before the introduction of $C$. gariepinus. Oxidation-reduction cycling of the zinc and its interactions with the organic materials in the manures and fertilizer could contribute to stress and damage observed in the $C$. gariepinus. It would be necessary to carry out further studies to understand interactions of zinc with $C$. gariepinus and manure at longer time periods and at lower concentrations.

\section{REFERENCES}

Agency for Toxic Substances and Disease Registry, ATSDR (2005). Toxicological Profile for zinc. United States Department of Health and Human Service, Agency for Toxic Substances and Disease Registry, (2005). United States Department of Health and Human Services, Public Health Service, Agency for Toxic Substances and Disease Registry.

Bouain N, Shahzad Z, Rouached A, Abbas Khan G, Berthomieu P, Abdelly C, Poirier Y, Pouached H. (2014). Phosphate and zinc transport and signalling in plants: towards a better understanding of their homeostasis interaction. Journal of Experimental Botany, 65(20): 5725-5741, 30th July, 2014. DOI: HTTPS// Doi.org/ 10.1093/jxb/eru314.

Broadley MR, White PJ, Hammond JP, Zelko I, Lux A (2007). "Zinc in plants". New phytologist 173 (4): p. 677.

Dacie, JV and Lewis SM (1975). Practical haematology, Fifth edition. Churchill Living Stone. 285 pp.

Ezeonyejiaku CD, Obiakor MO, Ezenwelu CO, Ugochukwu GC. (2010). Lethal Influence of Zinc Exposure to Clarias gariepinus (Burchell, 1822, Pisces, Clariidae). World Journal of Fish and Marine Sciences, 2(5):455-460, IDOSI Publications, 2010.

Ezeonyejiaku CD, Obiakor MO, Ezenwelu CO (2012). Lethal Influence of Zinc Exposure to Clarias gariepinus (Burchell, 1822, Pisces, Clariidae). Journal of Animal Science Advances, 2012, 2(1):177-183

Fırat O, and Kargın F (2010a). Biochemical alteration induced by $\mathrm{Zn}$ and $\mathrm{Cd}$ individually or in combination in the serum of Oreochromis niloticus. Fish Physiology and Biochemistry 36:647-653

Fırat $O$, and Kargın $F(2010 b)$. Individual and combined effects of heavy metals on serum biochemistry of Nile tilapia Oreochromis niloticus. Archives of Environmental Contamination and Toxicology. 58:151157.

Frassinetti S, Bronzetti G, Caltavuturo L, Cini M, and Croce (2006). The Role of Zinc in life: A Review. Journal of Environmental Pathology, Toxicology, and Oncology, 25(3) 597- 610.

Geeraerts C, Belpaire C (2010). The effects of contaminants in European eel: a review. Ecotoxicology (2010). 19:239-266. DOI 10.1007/s10646-009-0424-0

Gul A,Yilmaz M, Isilak Z (2009). Acute Toxicity of Zinc Sulphate $\left(\mathrm{ZnSO}_{4} \cdot \mathrm{H}_{2} \mathrm{O}\right)$ to Guppies (Poecilia reticulata). Gazi University Journal of Science 22(2): 59-65

Hallajian A, Ayoub Yousefi, Jourdehi A.Y, Kazemi R, and Shakuri M (2013). Acute effects of Zn (NO3)2 on gill and liver tissues of Silver Carp (Hypophthalmichthys molitrix). Science Research Essays 8(27) 1324-1327

Hambidge KM, Krebs NF (2007). "Zinc deficiency: a special challenge". Journal of Nutrition. 137 (4): p. 1011.

Hesser, E.F (1960). Methods of routine fish hematology. Progressive Fish Culturist. 22 (4): pp. 164-171.

Hogstrand C (2011). Zinc. Academic Press, New York, USA.

International Zinc Association (2017). Zinc in the environment. www.zinc.org accessed on 11th April, 2017.

Jabeen G, Javed M (2011). Evaluation of arsenic toxicity to biota in Ravi (Pakistan) aquatic ecosystem. Int J. Agric Biol. 13: 929-934.

Jain NC. 1986. Schalm's Veterinary Haematology. Lea \& Febiger, Philadelphia, 4: 8-18pp

Javed M. 2012. Effects of Zinc and lead toxicity on the growth and their bioaccumulation in fish. Pakistani Veterinary Journal, 32 (3): 357-362.

Langston WJ, Chesman BS, Burt GR, Pope ND, McEvoy J (2002) Metallothionein in liver of eels Anguilla anguilla from the Thames Estuary: an indicator of environmental quality? Mar Environ Res 53:263-293

Lenntech BV. (2017). Zinc. Rotterdamseweg 402 M, 2629 HH Delft

MAFF, 1984. Manual of veterinary investigation. Laboratory techniques. Volume 2, Reference Book 390. Third Edition. Ministry of Agriculture, Fisheries and Food, Her Majesty's Stationery Office, London, UK. 
Montgomery, HAC, Thom NS, Cockburn A. (1990). Determination of dissolved oxygen by winkler method and solubility of oxygen in pure and sea water. Journal of Applied Chemistry 14 (2): pp. 280-296.

Murphy J, Riley JP (1962). A modified single solution method for determination of phosphate in natural waters. Analytical Chemistry Acta 27: pp. 31-36.

Murugan SS, Karuppasamy R, Poongodi K, Puvaneswari S, 2008. Bioaccumulation Pattern of Zinc in Freshwater Fish Channa punctatus (Bloch.) after Chronic Exposure. Turkish Journal of Fisheries and Aquatic Sciences 8: 55-59

Nakashima AS and Dyck RH (2009). "Zinc and cortical plasticity." Brain Resource. Review. 59 (2): p. 347.

Ndimele PE (2009). Evaluation of Phyto-remediative properties of Water Hyacinthb (Eichhornia crassipes (Mart.) Solms) and Biostimulants in Restoration of Oil-Polluted wetlands the Niger Delta. A PhD thesis submitted to the Faculty of Agriculture and Forestry, University of Ibadan.

Olaifa FE, Omekam AJ (2014). Studies on Phytoremediation of Copper Using Pteridium aquilinum (Bracken Fern) In the Presence of Biostimulants and Bioassay Using Clarias gariepinus Juveniles. International Journal of Phytoremediation, 16: 219-234.Taylor and Francis Group, LLC

Ololade IA, Ogini O (2009). Behavioural and Hematological Effects of Zinc on African Catfish, Clarias gariepinus. International Journal of Fisheries and Aquaculture. 1(2) 022-027.

Pratt PF (1965). Digestion with perchloric and hydrochloric acid for total element. In methods of soil and plant analysis, pp. 1010-1021. American Society of Agronomy. Inc. Madison. Wisconsin, USA.

Ruttkay-Nedecky B, Nejdl L, Gumulec J, Zitka O, Masarik M, Eckschlager T, Stiborova M, Adam V, Kizek R (2013). Role of metallothioneins in oxidative stress. Int. J. Mol. Sci. 2013 Mar: 14(3)6044-6066.doi:10.3390/ijms 14036044

Schmitt CJ, Blazer VS, Dettloff GM, Tillitt DE, Gross TS, Bryant Jr, DoWeese WL, Smith SB, Geode RW, Bartish TM, Kublak TJ (1999). Assessing the exposure of fish to environmental contaminants. Information and Technology Report USGS/BRO - 1999 - 0007. U.S. Geological Survey, Biological Resources Division. Columbia. 547pp.
Tawari-Fufeyin P, Igetei J, Okoidogun ME (2008). Changes in the catfish exposed to acute cadmium and lead poisoning. Bioscience Research Communication 20: 271-276. Klobex Academic Publishers.

Trevisan R, Flesch S, Mattos JJ, Milani MR, Bainy ACD, Dafre AL (2014). Zinc causes acute impairment of glutathione metabolism followed by coordinated antioxidant defenses amplification in gills of brown mussels Perna perna. Comparative Biochemistry and Physiology, Part C 159, 22-30.

Valko M, Morris H, Cronin MTD (2005). Metals, Toxicity and Oxidative stress. Current Medicinal Chemistry 12: 1161

van Ginneken VJT, Bruijs M, Murk T, Palstra AP, van den Thillart GEEJM (2009). The effect of PCBs on the spawning migration of European silver eel (Anguilla anguilla L.). In: van den Thillart GEEJM, Dufour S, Rankin JC (eds.) Spawning migration of the European eel. Reproduction index, a useful tool for conservation management. Springer, New York, pp 363-384

Xu Qi, Chu W, Qiu H, Fu Y, Cai S, Sha S (2013). Responses of Hydrilla verticillata (L. f.) Royle to zinc: in situ localization, subcellular distribution and physiological and ultra-structural modifications. Plant physiology and biochemistry 69, 43-48. 